\title{
WHOLE BODY PHYSICAL TRAINING IN THE TREATMENT OF CHRONIC LOW BACK PAIN
}

\author{
TREINAMENTO FISICO DE CORPO INTEIRO NO TRATAMENTO DA DOR LOMBAR CRÔNICA \\ ENTRENAMIENTO FÍSICO DE CUERPO ENTERO EN EL TRATAMIENTO DEL DOLOR LUMBAR CRÓNICO
}

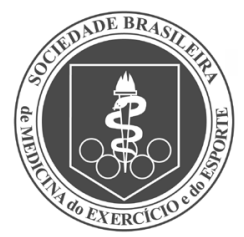

Original Article ARTIGo Original Artículo Original
Kaiya Xu' (D)

(Physical Education Professional)

1. Physical Education Department, Huaiyin Institute of Technology, Huaian, China.

\section{Correspondence:}

Physical Education Department, Huaiyin Institute of Technology, Huaian, 223200, China. xukaiya2010@163.com

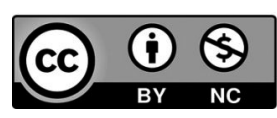

\begin{abstract}
Introduction: Chronic low back pain (CNLBP) manifests as chronic lumbosacral and hip pain, affecting athletes' daily training and competition. Whole-body sports training can significantly improve the strength of the core muscles of the lumbosacral region and has certain advantages in the treatment of chronic low back pain. Object: We study the therapeutic effect of whole-body physical training on athletes' chronic low back pain (CNLBP). Method: We selected 60 athletes with chronic low back pain patients. At the same time, we divide it into a control group and an observation group. The control group received conventional treatment, and the observation group received full-body physical training on this basis. After two months, the relevant physiological indicators of the patients were compared. Result: After treatment, all physiological indexes of the two groups have great differences. Conclusion: Whole-body physical training can significantly reduce athletes'back pain symptoms and help restore professional athletes to regular training. Level of evidence Il; Therapeutic studies - investigation of treatment results.
\end{abstract}

Keywords: Sports medicine; low back pain; core strength training; athletes; exercise.

\section{RESUMO}

Introdução: A dor lombar (GNP) crônica se manifesta como dor lombossacra e no quadril que afeta o treinamento e a competição diária dos atletas. O treinamento esportivo de corpo inteiro pode melhorar significativamente a força dos músculos centrais da região lombossacra e tem certas vantagens no tratamento da dor lombar crônica. Objetivo: Estudarmos o efeito terapêutico do treinamento físico de corpo inteiro na dor lombar crônica (CNLBP) em atletas. Método: Selecionamos 60 atletas com lombalgia crônica. Ao mesmo tempo, nós o dividimos em um grupo de controle e um grupo de observação. O grupo controle recebeu tratamento convencional e o grupo observação recebeu treinamento físico de corpo inteiro. Após dois meses, os indicadores fisiológicos relevantes dos pacientes foram comparados. Resultado: após o tratamento, todos os índices fisiológicos dos dois grupos apresentam grandes diferenças. Conclusão: O treinamento físico de corpo inteiro pode reduzir significativamente os sintomas de dor nas costas dos atletas e ajudar os atletas profissionais a voltarem a treinar regularmente. Nível de evidência ll; Estudos terapêuticos: investigação dos resultados do tratamento.

Descritores: Medicina esportativa; dor lombar; treinamento de força central; Atletas; exercício físico.

\section{RESUMEN}

Introducción: El dolor lumbar crónico (DPNG) se manifiesta como dolor lumbosacro y de cadera crónico que afecta el entrenamiento y la competición diaria de los deportistas. El entrenamiento deportivo de cuerpo entero puede mejorar significativamente la fuerza de los músculos centrales de la región lumbosacra y tiene ciertas ventajas en el tratamiento del dolor lumbar crónico. Objeto: Estudiamos el efecto terapéutico del entrenamiento físico de cuerpo entero sobre el dolor lumbar crónico (CNLBP) de los deportistas. Método: Seleccionamos a 60 deportistas con lumbalgia crónica. Al mismo tiempo, lo dividimos en un grupo de control y un grupo de observación. El grupo de control recibió tratamiento convencional y el grupo de observación recibió entrenamiento fisico de cuerpo completo. Después de dos meses, se compararon los indicadores fisiológicos relevantes de los pacientes. Resultado: después del tratamiento, todos los índices fisiológicos de los dos grupos tienen grandes diferencias. Conclusión: El entrenamiento físico de todo el cuerpo puede reducir significativamente los sintomas de dolor de espalda de los atletas y ayudar a que los atletas profesionales vuelvan a entrenar regularmente. Nivel de evidencia ll; Estudios terapéuticos: investigación de los resultados del tratamiento.

Descriptores: Medicina deportiva; dor de la región lombar; entrenamiento de fuerza central; Atletas; ejercicio físico.

\section{INTRODUCTION}

Low back pain (LBP) is one of the most common diseases of professional athletes. It is reported that the prevalence of LBP in young athletes in China is 20\%-40\%, of which more than $85 \%$ are non-specific low back pain (NLBP) that excludes a clear pathological anatomical cause. Chronic non-specific low back pain (CNLBP) manifests as chronic lumbosacral and hip pain, affecting athletes' daily training and competition. The treatment of CNLBP has become an essential issue in the field of sports rehabilitation. ' Core 
strength training can significantly improve the lumbosacral region's core muscle strength to improve the stability, coordination, and anti-interference of the lumbosacral region. It has certain advantages in the treatment of NLBP. However, domestic reports on its use in CNLBP rehabilitation for professional athletes are relatively scarce. Professional athletes have good training and exercise habits and have a higher grasp of treatment content. Core strength training can obtain better clinical effects. Therefore, this study uses prospective controlled experiments to clarify further the therapeutic effect and mechanism of core strength training on athletes' CNLBP.

\section{METHOD}

\section{General information}

The subjects of this study included 60 athlete CNLBP patients treated by our center from June 2018 to June 2020. ${ }^{2}$ There was no statistically significant difference in general information between the two groups (P>0.05), and they were comparable.

\section{Treatment methods}

Patients in the control group received conventional physical therapy. (1) Shortwave therapy. We place the probes of the ultrashort wave treatment instrument in front and back of the shoulder joints, with an air gap of 1.0-2.0cm, a current of 80-100mA, and the patient's sense of warmth. (2) Interference electrical therapy. We use the Minado-type interference electric therapy instrument produced by $\mathrm{H}$. With three groups of four-channel suction treatment heads, the positive rotation current frequency is $50000 \mathrm{~Hz}$, the difference is a fixed value between $1-100 \mathrm{~Hz}$, the patient lies on the bed, and the four electrodes of each channel are placed on the pain area of the waist. Strength, personal comfort and muscle contraction shall prevail. ${ }^{3}$

The observation group used core strength training based on the treatment of the control group. (1) Double bridge exercise: Switch to the supine position, place your hands horizontally on both sides, bring your calves together and place them on the Swiss ball, raise your hips to balance the Swiss ball and ensure that your shoulders, pelvis and feet are in a straight line., Maintain the 30s, ten times per group. (2) Single-bridge exercise: Instead of slowly lifting one lower limb based on double-bridge exercise, hold for 15s, then change the other lower limb to complete the same movement, ten times in each group. (3) Double-knee flexion and double-bridge exercise: Based on the double-bridge exercise, pull the Swiss ball with both feet to the hips, flex the knee joints and keep the shoulders, hips, and knee joints same straight line for 15s, ten times in each group. (4) Anti-bridge exercise: Lie on your back on the Swiss ball, lay your feet flat with shoulder width, knee flexion and maintain $90^{\circ}$ for about 1 min, ten times per group. (5) Inertial knee joint flexion and anti-bridge movement: based on the anti-bridge movement, unilateral falcon joint flexion is $90^{\circ}$, and the other side of the lower limb is maintained for 10 seconds to repeat the movement ten times per group.

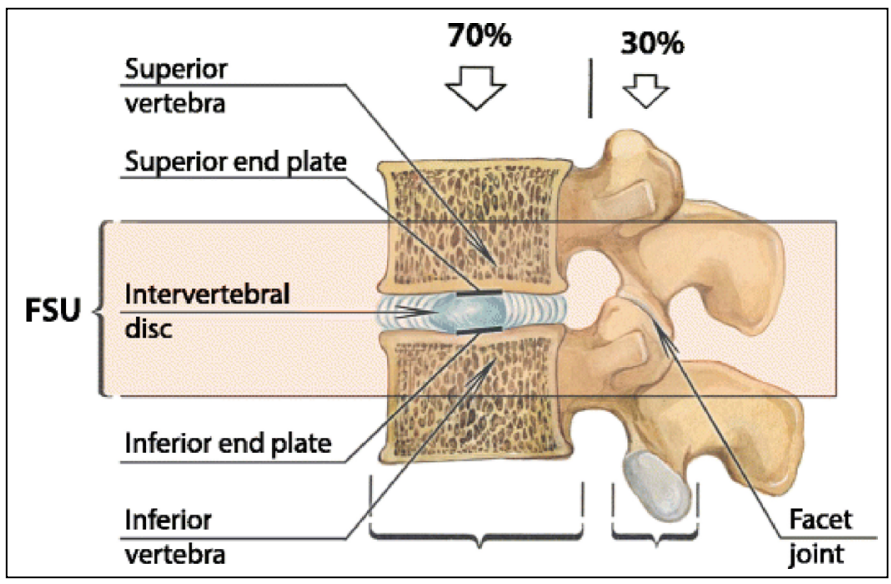

Figure 1. Schematic diagram of related indicators of lumbosacral structure.

\section{Observation indicators}

The visual analog scale of pain (VAS): The patient moves the cursor on the visual analog card according to the severity of pain, with a total of 10 scales, $0 \mathrm{~cm}$ means no pain, and $10 \mathrm{~cm}$ means intolerable.

Roland-Morris dysfunction (RDQ) score: including 12 basic actions such as lifting, walking, outing, etc., with a total score of 24 points. The higher the score, the more severe the dysfunction.

Lumbar spine disorders (JOA) score: Refer to the Japanese Society of Orthopedics (29-point system). The higher the score, the better the functional status. The total lumbar lordosis (TLL), sacral inclination (SI), and lumbar spine angle (LSA) measurements are shown in Figure 1.

\subsection{Statistical methods}

We use the $x 2$ test and t-test. The current statistical model believes that the acceleration of the target at the next moment will always change near the acceleration at the current moment, so we established the acceleration probability distribution function based on the modified Rayleigh distribution and used it as an adaptive factor to update iteratively. ${ }^{4}$ The probability density distribution function of the modified Rayleigh distribution is:

$$
f(a)=\frac{\left(a_{\max }-a\right)^{2}}{\sigma^{2}} e^{-\frac{x^{2}}{\sigma^{2}}},(a \geq 0)
$$

In formula (1) $a_{\max }$ is the maximum acceleration, a is the standard acceleration of the target at the current moment, and $\sigma$ is a known constant..$^{5}$ According to the principle of Rayleigh distribution, the mean $\mathrm{E}(\mathrm{a})$ and variance $\mathrm{D}(\mathrm{a})$ can be calculated ${ }^{6}$ :

$\left\{\begin{array}{l}E(a)=a_{\max }-\sqrt{\frac{\pi}{2}} \sigma \\ D(a)=\frac{4-\pi}{2} \sigma^{2}\end{array}\right.$

Combining formula (2) can get:

$$
D(a)=\frac{4-\pi}{2}\left(a_{\max }-E(a)\right)^{2}
$$

Among them, $E(a)$ can be equivalent to the best-estimated value of acceleration in the state equation. ${ }^{7}$ The prototype function of the state equation is

$\left\{\begin{array}{l}a=E(a)+\gamma(t) \\ \dot{a}=-\lambda a+\omega(t)\end{array}\right.$

$\lambda$ is the reciprocal of the body constant, $\gamma(t)$ is colored noise, $\omega(t)$ is white noise, and the variance is $2 \lambda D(a)$. At the same time, the equation of state is listed: 
$W(k)$ is obtained by discretization $\omega(t)$, and the discretization of formula (5) can be obtained as the following formula:

$\left(\begin{array}{l}x(k+1) \\ v(k+1) \\ a(k+1)\end{array}\right)=\left(\begin{array}{ccc}1 & T & \frac{-1+\lambda t+e^{-\lambda t}}{\lambda^{2}} \\ 0 & 1 & \frac{1-e^{-\lambda t}}{\lambda} \\ 0 & 0 & -e^{-\lambda t}\end{array}\right)\left(\begin{array}{l}x(k) \\ v(k) \\ a(k)\end{array}\right)+\left(\begin{array}{l}\frac{1}{\lambda}\left(-t+\frac{\lambda t^{2}}{2}+\frac{1-e^{-\lambda t}}{\lambda}\right) \\ t-\frac{1-e^{-\lambda t}}{\lambda} \\ 1-e^{-\lambda t}\end{array}\right) E(a)+W(k) \quad(6)$

For the body movement target, the acceleration of the target changes from the horizontal and lateral direction, affecting the adjustment accuracy of the "current" acceleration adaptive variance. The expression is as follows:

$$
\delta^{2}=\left\{\begin{array}{l}
\frac{4-\pi}{\pi}\left(a_{\max }+X k f(a)\right), X k f(a) \leq 0 \\
\frac{4-\pi}{\pi}\left(a_{\max }-X k f(a)\right), X k f(a)>0
\end{array}\right.
$$

The adjustment formula of $a_{\max }$ value is as follows:

$$
\max (k)=\left\{\begin{array}{l}
a_{\max }(k-1)+\rho a_{t j} \lambda,\left(\rho<\Delta_{j x}\right) \\
\gamma a_{\max }(k-1),\left(\rho \geq \Delta_{j x}\right)
\end{array}\right.
$$

In formula (9), $\mathrm{k}$ and ( $\mathrm{k}-1)$ represent adjacent moments, $\Delta_{j x}$ is the limit threshold (mainly used to determine the mutation point), $a_{t j}$ is the acceleration adjustment value, obtained through experience, and $\gamma$ is the adjustment when the maximum acceleration is adjusted quickly Factor, whose value is greater than 1. The exact frequency as $a_{\max }$ Adjust to improve rapid adaptability. ${ }^{8}$

$$
\$_{\rho}=\frac{\sum_{i=k-n}^{k} \rho_{i} \rho_{i}^{T}}{n}
$$

Substituting formula (10) into the Kalman filter formula, the expanded Kalman gain can be obtained as:

$$
K_{g}=P_{0-} \operatorname{preH}^{T} S_{\rho}
$$

\section{RESULTS}

\section{Comparison of function and symptom indicators}

Before treatment, the difference in VAS score, RDQ score and JOA score between the two groups was not statistically significant $(P>0.05)$; after treatment, the VAS score and RDQ score of the two groups were significantly lower than before treatment $(P<0.01)$, and the JOA scores were both Significantly increased $(P<0.01)$, and the changes in the three indicators in the observation group after treatment were more significant than those in the control group $(P<0.01)$. (Table 1)

\section{Comparison of waist structure changes}

There was no significant difference in TLL, SI and LSA between the two groups before treatment $(P>0.05)$; after treatment, $T L L$ and $S I$ in the observation group were significantly higher than those in the control group $(P<0.01)$, and LSA was lower than the control group $(P<0.05)$. (Table 2)

\section{Comparison of clinical efficacy}

The total effective rate of treatment in the observation group was 93.33\%, which was not statistically different from $83.33 \%$ in the control group (P>0.05). (Table 3)

Table 1. Comparison of 2 groups of function and symptom indicators.

\begin{tabular}{c|c|c|c|c}
\hline Grouping & $\mathbf{n}$ & VAS score & RDQ score & JOA score \\
\hline Before therapy & & & & \\
\hline Observation group & 30 & $6.56 \pm 0.98$ & $15.02 \pm 2.32$ & $16.34 \pm 2.23$ \\
\hline Control group & 30 & $6.60 \pm 1.00$ & $14.97 \pm 2.25$ & $16.37 \pm 2.20$ \\
\hline $\mathrm{t}$ & - & 0.16 & 0.08 & 0.05 \\
\hline $\mathrm{P}$ & - & $>0.05$ & $>0.05$ & $>0.05$ \\
\hline After treatment & & & & \\
\hline Observation group & 30 & $1.32 \pm 0.28$ & $4.01 \pm 0.67$ & $24.12 \pm 2.61$ \\
\hline Control group & 30 & $1.70 \pm 0.30$ & $5.43 \pm 0.70$ & $22.02 \pm 2.32$ \\
\hline $\mathrm{t}$ & - & 5.07 & 8.03 & 3.29 \\
\hline $\mathrm{P}$ & - & $<0.01$ & $<0.01$ & $<0.01$ \\
\hline
\end{tabular}

Table 2. Comparison of lumbosacral structural changes in the two groups.

\begin{tabular}{c|c|c|c|c}
\hline Grouping & $\mathbf{n}$ & TLL & SI & LSA \\
\hline before therapy & & & & \\
\hline Observation group & 30 & $42.34 \pm 3.03$ & $37.02 \pm 2.11$ & $137.24 \pm 12.12$ \\
\hline Control group & 30 & $42.30 \pm 3.05$ & $36.96 \pm 2.14$ & $137.30 \pm 12.20$ \\
\hline $\mathrm{t}$ & - & 0.05 & 0.11 & 0.02 \\
\hline $\mathrm{P}$ & - & $>0.05$ & $>0.05$ & $>0.05$ \\
\hline After treatment & & & & \\
\hline Observation group & 30 & $46.23 \pm 3.18$ & $39.98 \pm 2.62$ & $131.11 \pm 10.21$ \\
\hline Control group & 30 & $43.10 \pm 3.07$ & $37.26 \pm 2.30$ & $136.32 \pm 12.32$ \\
\hline $\mathrm{t}$ & - & 3.88 & 4.27 & 2.08 \\
\hline $\mathrm{P}$ & - & $<0.01$ & $<0.01$ & $<0.05$ \\
\hline
\end{tabular}

Table 3. Comparison of clinical efficacy between the two groups.

\begin{tabular}{c|c|c|c}
\hline Grouping & Observation group & Control group & Total \\
\hline $\mathrm{n}$ & 30 & 30 & 60 \\
\hline Get well & $12(40.00)$ & $8(26.67)$ & $20(33.33)$ \\
\hline Significantly effective & $13(43.00)$ & $12(40.00)$ & $25(41.67)$ \\
\hline Effective & $3(10.00)$ & $5(16.67)$ & $8(13.33)$ \\
\hline invalid & $2(6.67)$ & $2(6.06)$ & $4(0.67)$ \\
\hline Efficient/\% & 93.33 & 83.33 & 88.33 \\
\hline$X 2$ & \multicolumn{3}{|c}{0.65} \\
\hline$P$ & $>0.05$ \\
\hline
\end{tabular}

\section{DISCUSSION}

Professional athletes generally spend more than 2 hours in each training session. It is challenging to avoid upper body strength exercises, bending exercises, and waist movements beyond the physiological range, so LBP is prone to occur. Most of the athletes' LBP patients treated in our center have no apparent organic injury, mostly CNLBP. The typical symptoms are chronic lumbosacral and hip pain for more than three months. The low back pain increases when the training intensity increases, decreasing when the training volume decreases. Athletes'standard training and competition cause continuous impact. ${ }^{9}$

In this study, patients in the control group were given conventional treatment. Interference electricity can act on deep tissues, produce electrical stimulation to the tissues, inhibit sensory nerves, and increase pain threshold; it can produce low-frequency dynamic three-dimensional stimulation of different angles, directions, and shapes., Produces vasodilation effect, promotes blood and lymph circulation in deep tissues of the waist, accelerates the absorption of exudates, and relieves pain symptoms. The warming effect of shortwave can reach the deep tissues 
of the human body, improve tissue blood and lymph circulation, and at the same time promote the absorption of inflammatory substances in painful parts, promote the elimination of edema, to exert the effect of swelling, pain relief and inflammation elimination. The total effective rate of treatment in the control group in this study is $83.33 \%$, but regardless of the total effective rate or functional symptoms such as VAS score, RDQ score, JOA score, the observation group has better therapeutic effects, which is the same as the observation group using core strength training Have a direct relationship. With the gradual deepening of NLBP research, studies believe that chronic LBP is directly related to decreased lumbosacral stability.

Regarding the lumbosacral structure, CNLBP and other reports stated that the sacral tilt and L4-5 curvature of CNLBP patients had a downward trend compared with the average physical examination population, and they had apparent lumbosacral and pelvic tilt. In contrast, the control group had no significant changes in the lumbosacral structure before and after treatment, indicating that core strength training improved. The effect of CNLBP rehabilitation for athletes is also related to improving lumbosacral structure. In this study, the core strength training has a slightly better effect on treating athletes with CNLBP patients than previously reported. This may be related to the athletes' higher mastery of training movements and better training effects.

\section{CONCLUSION}

In summary, core strength training can significantly reduce the symptoms of low back pain in athletes with CNLBP, improve dysfunction and the degree of lumbosacral and pelvic tilt, and help restore professional athletes' standard training. It is suitable for the rehabilitation of athletes with CNLBP.

$\overline{\text { The author declare no potential conflict of interest related to this article }}$

AUTHORS' CONTRIBUTIONS: The author made significant contributions to this manuscript. Kaiya Xu: writing and performing surgeries; data analysis and performing surgeries; article review and intellectual concept of the article

\section{REFERENCES}

1. Khodadad B, Letafatkar A, Hadadnezhad M, Shojaedin S. Comparing the effectiveness of cognitive functional treatment and lumbar stabilization treatment on pain and movement control in patients with low back pain. Sports Health. 2020;12(3):289-95.

2. La Touche R, Grande-Alonso M, Cuenca-Martínez F, Gónzález-Ferrero L, Suso-Martí L, Paris-Alemany A. Diminished kinesthetic and visual motor imagery ability in adults with chronic low back pain. PM R. 2019;11(3):227-35

3. Riley SP, Swanson BT, Dyer E. Are movement-based classification systems more effective than therapeutic exercise or guideline based care in improving outcomes for patients with chronic low back pain? A systematic review. J Man Manip Ther. 2019;27(1):5-14.

4. Matheve T, De Baets L, Bogaerts K, Timmermans A. Lumbar range of motion in chronic low back pain is predicted by task-specific, but not by general measures of pain-related fear. Eur J Pain. 2019;23(6):1171-84.
5. Lanier VM, Lang CE, Van Dillen LR. Motor skill training in musculoskeletal pain: a case report in chronic low back pain. Disabil Rehabil. 2019;41(17):2071-9.

6. Gizzi L, Röhrle O, Petzke F, Falla D. People with low back pain show reduced movement complexity during their most active daily tasks. Eur J Pain. 2019;23(2):410-8.

7. Hodges PW. Hybrid approach to treatment tailoring for low back pain: a proposed model of care. J Orthop Sports Phys Ther. 2019;49(6):453-63.

8. van Dieën JH, Reeves NP, Kawchuk G, van Dillen LR, Hodges PW. Motor control changes in low back pain: divergence in presentations and mechanisms. J Orthop Sports Phys Ther. 2019;49(6):370-9.

9. Baillie L, Bacon CJ, Hewitt CM, Moran RW. Predictors of functional improvement in people with chronic low back pain following a graded Pilates-based exercise programme. J Bodyw Mov Ther. 2019;23(1):211-8. 